\title{
Why Thai Tax-Benefit Funds Are Popular with Investors?
}

\author{
Somkid YAKEAN ${ }^{1}$
}

Received: September 01, 2020 Revised: October 26, 2020 Accepted: November 05, 2020

\begin{abstract}
Investing in the tax-benefit funds is the best way for the inexperienced investors who do not have knowledge, expertise, and the time to research the information by themselves. This study describes the benefits of tax-benefit funds in Thailand. The tax-benefit funds consist of retirement mutual funds (RMFs) and super saving funds (SSFs). There are many kinds of funds investment policies on offer. The tax-benefit funds provide the opportunity to investors, which they are able to invest a small amount and draw more benefits. They hire fund managers to manage their money. These funds are able to help investors to meet their goals. The RMFs are suitable for investors who want to have money for retirement, investing every year, and getting tax exemption. The investors who invest in RMFs are able to deduct the tax income by including other retirement funds not exceeding THB500,000.00 per year. The SSFs match for the investors who need to obtain the tax exemption and long-term investment for at least ten years. The SSFs provide the benefit to investors that they are able to deduct taxable income not more than THB200,000.00 per year. Finally, these funds are tax-except and promoted for retirement savings.
\end{abstract}

Keywords: Mutual Funds, Tax-Benefit Funds, Thai Mutual Funds, Super Saving Funds

JEL Classification Code: G10, G19, G23

\section{Introduction}

Mutual funds are the financial instruments that collected money from investors and invest in equity, fixed-income instruments, money-market instruments, and other assets on their behalf. These financial instruments provide the benefits for investors who lack of knowledge, non-expert, or having no time to research by themselves to reach their investment goal. These financial instruments are systematic investment management able to help investors to achieve the best returns within the acceptable risk parameters. These financial instruments play a significant role in driving the economic growth and supporting the growth of the capital market. They help investors to diversify risk and have professional management to invest in any class of financial instruments

${ }^{1}$ First Author and Corresponding Author. Lecturer, Finance and Banking Department, School of Business and Communication Arts, University of Phayao, Phayao, Thailand [Postal Address: 19, Moo 2, Tambon Maeka, Amphur Muang, Phayao, 56000, Thailand]

Email: audyken@gmail.com

(c) Copyright: The Author(s)

This is an Open Access article distributed under the terms of the Creative Commons Attribution Non-Commercial License (https://creativecommons.org/licenses/by-nc/4.0/) which permits unrestricted non-commercial use, distribution, and reproduction in any medium, provided the original work is properly cited. on their behalf. They also provide benefits to investors like liquidity, flexibility, and convenience.

In 1975, the Thai mutual was initiated through a collaboration between the Thai government and the International Finance Corporation (IFC) to set up the first asset management company in Thailand, named the Mutual Fund Public Co., Ltd. Thai mutual market is known as "an emerging mutual market" since the financial market in Thailand is in the stage of development. It is one of the fastest-growing mutual funds market in the Asia/Pacific region. According to the sell/buy unit of funds, the Thai mutual funds can be broadly grouped into closed-ended funds and open-ended funds. The former is a fixed number of units of funds, which investors can redeem at the maturity date. To provide the liquidity for the investors, these funds trade in the organized exchange market in which the price of unit funds can be discount funds or premium funds depending on the supply and demand in the mutual market. The latter is an unlimited number of units of funds which investors can sell or redeem through the asset management companies or selling agents every time their wish. These funds purchase and sell at the Net Asset Value (NAV). The NVA is determined by the total value of the current market value of fund's assets plus other income minus current liabilities minus other expenses and divided by the number of units of funds. 
Moreover, Thai mutual funds can be categorized into five groups according to investment policies. First, it is known as an equity fund, which primarily aims to be invested in the stock market. Second, this fund is called a fixed-income fund, which aims to be invested in fixed income instruments, such as government bonds and corporate bonds. This fund comprises short-term fixed-income funds and long-term fixed-income funds according to the duration of their assets. The former is invested in fixed-income instruments that have a maturity date less than one year, while the latter is invested in fixed-income instruments that have a maturity date more than one year. Third, this fund is called a mixed fund, which stipulates the fund is to be invested in stocks, fixed income instruments, or money market instruments to get both income and capital growth. This fund will be invested in both fixedincome instruments and equity instruments, with a flexible ratio range between $35-65 \%$ of total assets, depending on the financial market situations. The difference between equity fund, fixed-income fund, and mixed fund is only the proportional requirement of the portfolio holding. Fourth, the fund is mainly invested in real estate, so it is called a property fund and Real Estate Investment Trust (REIT). Fifth, this fund joins other funds that are not falling in any previous groups, such as funds of funds, guaranteed funds, and tax-benefit funds.

\section{Objective}

This study aims to explore the tax-benefit funds in Thailand.

\section{Information of Tax-Benefit Funds}

\subsection{Tax-Benefit Funds}

The government had launched the tax-benefit funds to facilitate people to save money for their retirement and to enhance stability in the capital market. These funds consist of the retirement mutual fund (RMF) and long-term mutual fund (LTF). The former was established on February $22^{\text {nd }}$, 2002 , with the purpose to stimulate people to save money for their retirement. These funds also meet the requirement of the World Bank's 'three pillars' pension system because it provides an alternative form of retirement savings. Investors who invest in these funds are able to choose any investment policies. So, these funds are able to help the investors meet their risk acceptance and expected returns. The latter was established on April $27^{\text {th }}$, 2004, under the Thai capital market development strategy. The objectives of LTF were to increase the proportion of long-term investment and to increase the number of investors participating in the Stock Exchange of Thailand. The core objective was to help stabilize the index volatility trading by foreign investors, and internal individual investors to make a more stable market. Both tax-benefit funds are opened-end funds as categorized by the number of units of funds and trading procedure.

The RMFs give benefits to all participants as they receive a current-year tax deduction on contributions. The maximum contribution is $30 \%$ of total annual income, but not more than THB500,000 per year (whichever is lower) from currentyear taxable income. The total contribution of RMFs, including provident funds not exceeding THB500,000, are tax-exempted. This fund stipulates a continuous investment for at least five years and can be redeemed when the investors are over 55 years old. If the investors withdraw funds prior reaching the age of 55, not meet the five-year holding period, or fail to meet the requirement of the contribution schedule, the investors must pay back any tax deduction along with penalty fees. They also must pay $10 \%$ of the tax on capital gains. These funds are invested in all financial instruments.

The LTFs offer tax privileges to all investors, in which the investors are required to hold a unit of funds total of five years. In 2016, the government had changed the rules holding a period, which required the investors to hold the units of funds a total of seven years. In 2019, this was the last year for the investors to get the tax benefits from LTFs, and is replaced by super saving funds (SSFs). This fund provides benefits to investors that are able to deduct a current-year tax deduction on contributions. The maximum contribution is $15 \%$ of total annual income, but not more than THB500,000, excluding the amount of contribution RMFs, Provident Fund, Government Pension Fund, Private Teacher AID Fund, National Savings Fund, and Life Insurance for Retirement. The returns from this fund are tax-exempted. This fund is no required to be invested every year for maintaining tax benefits. If the investors withdraw funds prior to reaching the five-year holding period or seven-year holding period, the investors must pay back any tax deduction along with penalty fees. They also must pay $10 \%$ of the tax on capital gains. The contribution on these funds must be recorded by the end of the calendar year. On the other hand, even if all the funds are invested in the same share, the return may not be equal, because each fund has a different investment policy, share characteristics, as well as the fund managers' ability. There are two types of LTFs, namely, LTF with dividend payout policy and LTF without dividend payout policy. They have different characteristics. The LTF with dividend policy pays a consistent stream of income throughout the holding period, but there are liable to pay a 10-percent withholding tax on dividends. These funds cannot help investors to diversify portfolios properly because these funds are only invested in the Stock Exchange of Thailand.

In 2020, the Government had established the SSFs with substitute LTFs. This fund aims to promote early savings and retirement planning among people. This fund also intends to encourage people to save money for a long-term 
basis up to 10 years and reward them with deductions from their taxable incomes. This fund is an opened-end fund as categorized by the number of units of funds and sell and redeem procedures. Investing in SSFs is tax-deductible up to $30 \%$ of an investor's taxable income, but not more than THB200,000. The total amount of investment in SSFs and other retirement funds such as RMFs, Provident Fund, Government Pension Fund, Private Teacher AID Fund, National Savings Fund, or Life Insurance for Retirement must not exceed THB500,000 a year. This fund is unlike LTFs, it is invested in all types of financial instruments. There is no minimum purchase on this fund and no requirement to purchase every year. At the same time, fund-holders are able to switch to other funds. This fund replaces LTFs, while doubling the amount people are able to invest in RMFs. This fund requires investors to hold units of funds for ten years to be able to get tax benefits. Revenues from the sale of SSF investments are tax-exempted. The tax-deductible is valid for five years. This fund determines investors to invest in SSFs from January 1, 2020, to December 31, 2024 (five years) to eligible tax incentives in any year they are invested in the SSFs. If the investors withdraw before the ten-years holding period, any tax deductions they received must be payback. They also pay additional tax with a surcharge of $1.5 \%$ per month. Capital gains will also be subject to tax in the year that they are sell. In addition, the investors must retain the certificate of investment in the SSFs issued by the asset management company to support the tax exemption. The fund-holders may transfer an investment in one SSFs to another SSFs. If the investors cannot make the transfer of
SSFs funds within five working days, the investment period of 10 years will not be continued.

\section{Research Methodology}

\subsection{Source of Data}

This article obtained the data from secondary sources such as the Association of Investment Management Companies (AIMC), Bank of Thailand, and the Stock Exchange of Thailand (SET). This study used the mutual funds theories to analyze the tax-benefit funds information.

\subsection{The Evidence Growth of Tax-benefit funds}

The total net asset values of Thai mutual funds grew by more than $101.95 \%$ between 2013 and 2019. Despite the growth in asset values, the number of funds also increased from 1,380 funds in 2013 to 1,878 funds by the end of May 2020. Similarly, Figure 1 reveals the growth of Thai mutual funds.

As shown in Figure 1, the growth of the number of RMFs had increased nearly to the general equity funds. The growth of LTFs had increased every year. The SSFs started to sell in the mutual fund market in 2020 and is popular with investors as it increased every month.

Figure 2 shows Thai mutual fund assets.

As shown in Figure 2, the total asset values of the taxbenefit fund had increased every year. It indicated that the tax-benefit funds are attractive mutual funds for investors and match investment goals.

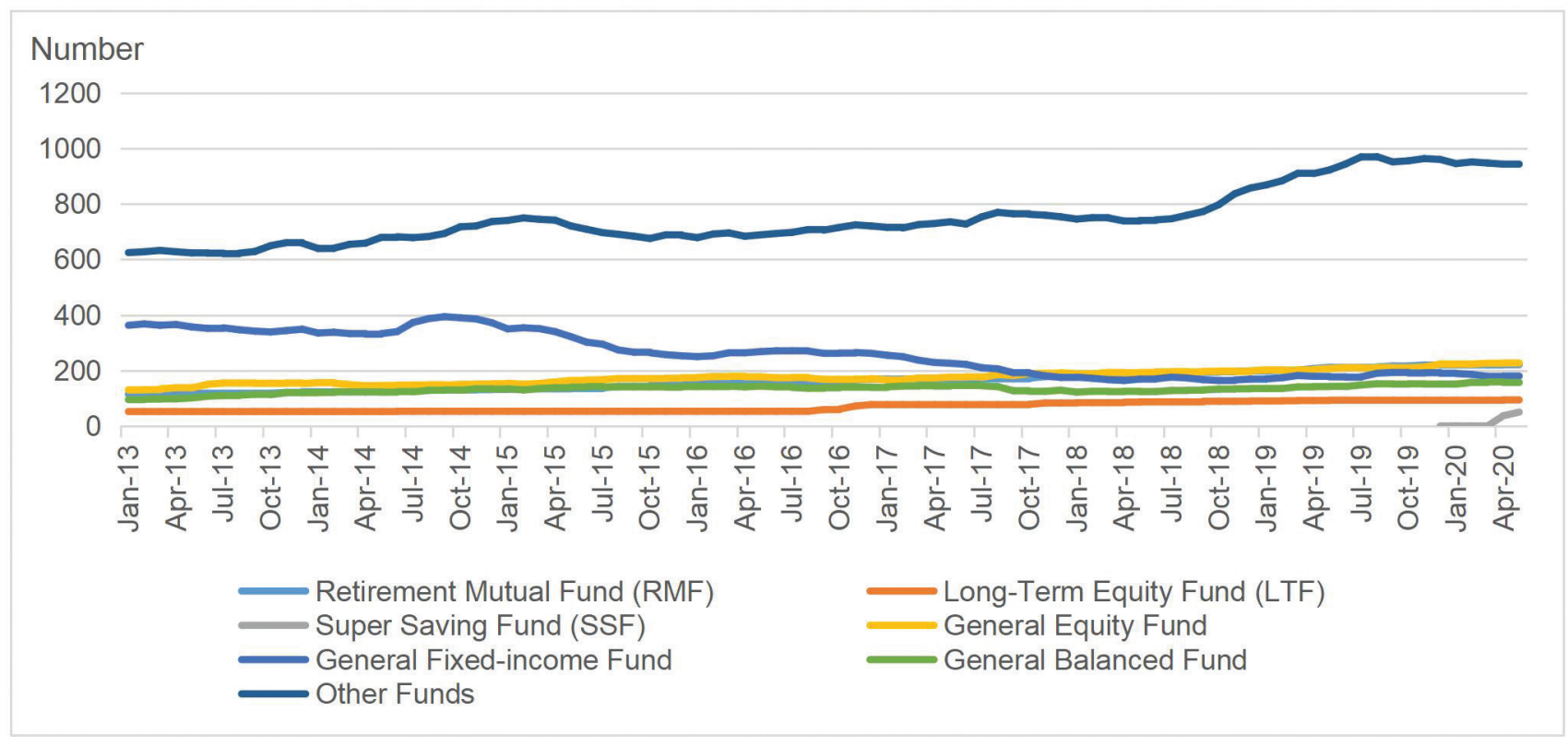

Figure 1: Number of Funds Classified by Special Fund Groups 


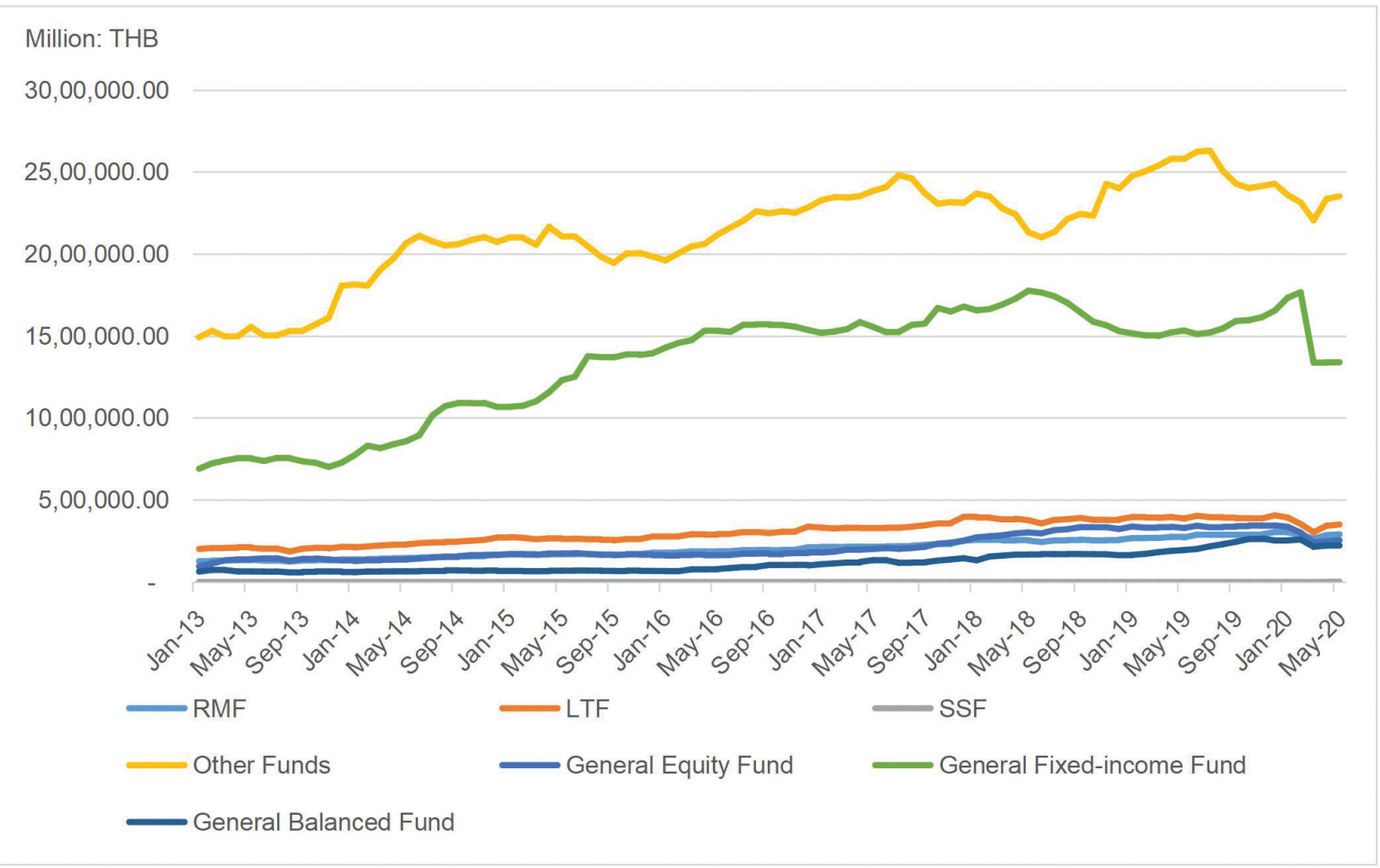

Figure 2: Total Net Asset Value Classified by Special Fund Groups

\section{Results}

\subsection{Comparison of Tax-Benefit Funds}

The major differences between the characteristics of RMFs, LTFs, and SSFs are summarized in Table 1.

\subsection{Who Can Benefit from Tax-benefits Funds?}

Thai citizens and foreigners with a long-term stay in Thailand for work, marriage, and lifestyle are able to benefit from investing in RMFs and SSFs. The RMFs match the people who want to save money for their retirement and are tax-exempted. The SSFs are suitable for middle-income people who want to get tax-exempted and long-term savings.

\section{Summary - Why Thai Tax-benefit Funds are Popular}

The following are the reasons why the tax-benefit funds are attractive to investors in Thailand:
1. These funds are tax-exempted.

2. These funds are able to help the investors to diversify risks because these funds are invested in different financial instruments.

3. These funds facilitate the investors to easily reach investment goals because they are invested in all types of financial instruments, which can get different kinds of returns.

4. When they reach retirement, investors have enough money to support their life.

5. Investors hire a professional fund manager to help them to invest in all financial instruments to achieve their investment goals.

6. Investors who invest in tax-benefits changed from individual investors to institutional investors. This helps them to have bargaining power in the financial market and access to crucial corporate information that individual investors cannot access.

7. These funds can be purchased and sold at management companies and trading agents through online and counter dealers. 
Table 1: Comparison of Thai Tax-Benefit Funds

\begin{tabular}{|c|c|c|c|}
\hline Description & RMFs & LTFs & SSFs \\
\hline $\begin{array}{l}\text { Minimum investment } \\
\text { requirement }\end{array}$ & No & No & No \\
\hline $\begin{array}{l}\text { Maximum investment } \\
\text { requirement cap (annual) }\end{array}$ & $\begin{array}{l}\text { Up to } 30 \% \text { of a year's taxable } \\
\text { income, but together with } \\
\text { investment in other retirement } \\
\text { funds, not exceeding THB } \\
500,000.00\end{array}$ & $\begin{array}{l}\text { Up to } 15 \% \text { of a year's taxable } \\
\text { income capped at THB } \\
500,000.00\end{array}$ & $\begin{array}{l}\text { Up to } 30 \% \text { of each year's } \\
\text { taxable income, capped } \\
\text { at THB } 200,000.00 \text { and } \\
\text { together with investment in } \\
\text { other retirement funds, not } \\
\text { exceeding THB } 500,000.00\end{array}$ \\
\hline $\begin{array}{l}\text { Minimum holding period to } \\
\text { receive tax incentive }\end{array}$ & $\begin{array}{l}5 \text { years from the date of initial } \\
\text { purchase, selling before the } \\
\text { age of } 55 \text { years removes } \\
\text { entitlement to tax incentive }\end{array}$ & $\begin{array}{l}7 \text { calendar years for LTF units } \\
\text { purchase between January } \\
\text { 1, } 2016 \text { and December } 31 \text {, } \\
2019 ; 5 \text { calendar years for } \\
\text { LTF units purchased prior } \\
\text { to January 1, } 2016 \text { (Tax } \\
\text { incentive discontinued after } \\
2019\end{array}$ & $\begin{array}{l}10 \text { years from the date of } \\
\text { purchase }\end{array}$ \\
\hline $\begin{array}{l}\text { Continual investment } \\
\text { requirement to receive tax } \\
\text { incentive }\end{array}$ & $\begin{array}{l}\text { Recurring investment at least } \\
\text { every } 2 \text { years to receive tax } \\
\text { incentive }\end{array}$ & $\begin{array}{l}\text { Tax incentive discontinued, } \\
\text { but investor can continue } \\
\text { to invest in the LTF, Prior to } \\
\text { this, no recurring investment } \\
\text { required }\end{array}$ & $\begin{array}{l}\text { No requirement, but } \\
\text { investment must be made } \\
\text { from January } 12020 \text { to } \\
\text { December } 312024 \text { to receive } \\
\text { tax incentive }\end{array}$ \\
\hline Tax-benefits & $\begin{array}{l}\text { Income tax credit ( } 30 \% \text { of } \\
\text { total income, maximum THB } \\
500,000.00)\end{array}$ & $\begin{array}{l}\text { Income tax credit (15\% of } \\
\text { total income, maximum THB } \\
500,000.00)\end{array}$ & $\begin{array}{l}\text { Income tax credit }(30 \% \text { of } \\
\text { total income, but not more } \\
\text { than THB } 200,000.00)\end{array}$ \\
\hline Investment Policy & $\begin{array}{l}\text { Any (Equity, Fixed-Income } \\
\text { Instruments, Mixed Funds, or } \\
\text { Other funds) }\end{array}$ & $\begin{array}{l}\text { Any (Equity, Fixed-Income } \\
\text { Instruments, Mixed Funds, or } \\
\text { Other funds) }\end{array}$ & $\begin{array}{l}\text { Any (Equity, Fixed-Income } \\
\text { Instruments, Mixed Funds, or } \\
\text { Other funds) }\end{array}$ \\
\hline Goal of funds & Encouraged for retirement & For growth of stock markets & $\begin{array}{l}\text { For retirement and long-term } \\
\text { saving funds }\end{array}$ \\
\hline Who Suit for these funds & $\begin{array}{l}\text { Freelance who do not have } \\
\text { other retirement funds plan }\end{array}$ & For high-income people & $\begin{array}{l}\text { For middle-income people } \\
\text { and who want to saving } \\
\text { money for a long-term }\end{array}$ \\
\hline Switching between funds & Yes & Yes & Yes \\
\hline Specified redemption date & No & $\begin{array}{l}\text { Yes (twice a year, on a } \\
\text { specified date) }\end{array}$ & No \\
\hline
\end{tabular}

\section{Conclusion}

Nowadays, people have many financial instruments to invest in, but if they select the wrong financial instruments, they will lose money. Tax-benefit funds provide tax benefits, liquidity, and professional fund manager for investors that will grow the economy by increased fund flow in the financial system. Thai tax-benefits funds consist of RMFs and SSFs with different goals and characteristics. Therefore, investors should understand the character of tax-benefits and know their investment goals. If they want to have money for retirement, investing every year, with tax exemption, they should invest in RMFs. Finally, if they need to get tax exemption and long-term investment for at least 10 years, they should invest in SSFs. 


\section{References}

Asset Management Public Company Limited. (2020). RMF \& LTF the Tax Benefit Twins Worth Investing In. Retrieved May 15, 2020, from https://www.mfcfund.com/mfc/images/pdf/LTF_RMF_en.pdf

Association of Investment Management Companies (AIMC). (2020). Historical Data. Retrieved May 15, 2020, from http:// ns3.aimc.or.th/web/downloadstat/

Stock Exchange of Thailand (SET). (2020). Let's Get to Know SSF, The New Savings Fund, and the New RMF Tax Threshold. Stock Exchange of Thailand.
Thai Mutual Fund. (2020). RMFs and LTFs Handbook. Retrieved May 15, 2020, from http://thaimutualfundnews.com/new/ content/view/419 (In Thai)

The Nation Newspaper. (2019, December 4). Market Welcomes New Tax Incentives for Long-Term Investment in Mutual Funds. The Nation Newspapers, Retrieved from https://www. nationthailand.com/business/30379050 